
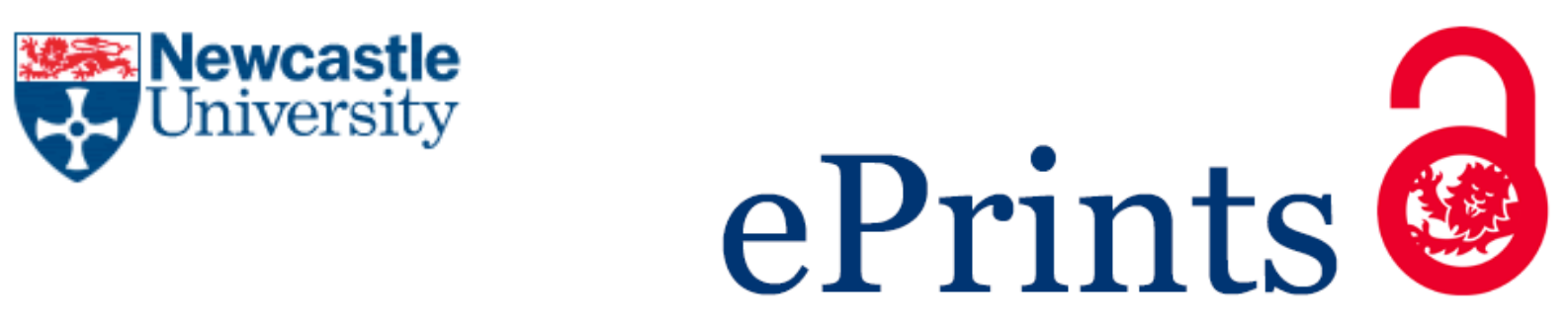

Bahemia H, Squire B, Cousins P.

A multi-dimensional approach for managing open innovation in NPD. International Journal of Operations and Production

Management 2017, 37(10), 1366-1385.

\title{
Copyright:
}

This is the authors' accepted manuscript of an article that has been published in its final definitive form by Emerald Publishing Group Ltd, 2017

DOI link to article:

https://doi.org/10.1108/IJOPM-07-2015-0415

Date deposited:

21/01/2017 


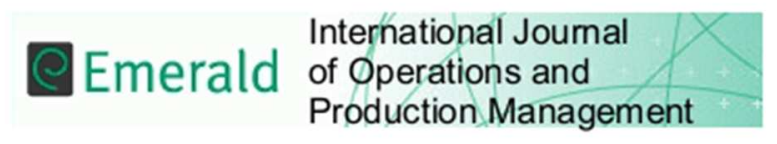

\section{A Multi-dimensional approach for managing open innovation in NPD.}

\begin{tabular}{|r|l|}
\hline Journal: & International Journal of Operations and Production Management \\
\hline Manuscript ID & IJOPM-07-2015-0415.R5 \\
\hline Manuscript Type: & Research Paper \\
\hline Keywords: & Innovation, New product development, Empirical, Integration \\
\hline \multicolumn{2}{|l}{} \\
\hline
\end{tabular}




\title{
A multi-dimensional approach for managing open innovation in NPD
}

\author{
Hanna Bahemia ${ }^{a}$, Brian Squire ${ }^{b^{*}}$, Paul D Cousins ${ }^{c}$ \\ ${ }^{\text {a }}$ Newcastle University Business School \\ University of Newcastle \\ Newcastle upon Tyne \\ NE1 4SE \\ United Kingdom \\ E-mail: hanna.bahemia@ncl.ac.uk \\ ${ }^{\mathrm{b}}$ HPC Supply Chain Innovation Lab \\ Information, Decisions and Operations Division \\ School of Management \\ University of Bath \\ BA2 7AY \\ United Kingdom \\ E-mail: b.c.squire@,bath.ac.uk \\ Tel: $+44(0) 1225384731$ \\ ${ }^{\mathrm{c}}$ Alliance Manchester Business School \\ The University of Manchester \\ Manchester \\ M13 9SS \\ United Kingdom \\ E-mail: paul.cousins@mbs.ac.uk
}

\footnotetext{
* Corresponding Author
} 
A multi-dimensional approach for managing open innovation in NPD

\section{Structured Abstract:}

\section{Purpose}

This paper explores openness within New Product Development (NPD) projects. Our study examines the impact of breadth, depth and partner newness on product innovativeness and product competitive advantage. We also seek to examine the contingent effects of the appropriability regime. We make suggestions to academics and practitioners based on our findings.

\section{Design/Methodology/Approach}

We use a structured survey instrument producing an empirical analysis of 205 NPD projects in the manufacturing sector in the UK. We use an ordinary least squares (OLS) regression model to test hypothesised relationships between openness (breadth, depth and partner newness), product innovativeness, product competitive advantage and the appropriability regime.

\section{Findings}

We find that each of the three dimensions of openness; depth, breadth and partner newness, have a significant but differing impact on product innovativeness. Specifically, our study indicates that breadth has a positive effect but only in the presence of a strong appropriability regime, partner newness has a direct positive effect, and depth has a direct negative effect. We also find that product innovativeness has a positive impact on product competitive advantage.

\section{Research Limitation/Implications}

Further research should focus on replicating the findings in other countries, search for further moderating factors, such as the stage of the NPD process, and analyse the longitudinal impact of openness within NPD projects.

\section{Practical Implications}

Organisations are encouraging managers to be more open in their approach to NPD. Our findings suggest that managers need to think about the three dimensions of openness; breadth, depth and partner newness. Their engagement with each of these dimensions depends on the desired outcomes of the innovation project and the strength of patents.

\section{Originality/Value.}

Our research extends the extant supplier involvement in new product development (SINPD) literature to examine the effect of up to 11 types of external actor in NPD projects. We test a new multi-dimensional measurement scale for the openness construct. We show that each dimension has a different relationship with product innovativeness.

Key words: new product development, open innovation, integration 


\section{Introduction}

The advantages of supplier involvement in New Product Development (NPD) are well established in the operations management literature (Primo and Amundson, 2002). Organisations who work closely with their suppliers during the innovation process realise benefits from increased learning opportunities and knowledge transfer, as well as enhancing capabilities not otherwise available in-house (Lawson, Petersen, Cousins, and Handfield, 2009; Petersen, Handfield, and Ragatz, 2005), leading to superior product commercialisation and project performance (Song and Di Benedetto, 2008; Yan and Dooley, 2013). Recent literature has started to focus on the role of other external parties also involved in NPD projects. For example, Mishra and Shah (2009) found the combination of customer, supplier and internal involvement creates a 'collaborative competence' that has a positive effect on both project and market performance. This wider integration argument is also supported by Frohlich and Westbrook's (2001) work on the 'arcs of integration'. They argue that firms with the widest arcs of integrations, i.e. the involvement of many partners and customers within their network, achieve higher levels of firm performance. Indeed, a broader unit of study appears critical to our understanding of the NPD process given that the number and diversity of parties involved in the project directly affects relationship dynamics and innovation outcomes (Laursen and Salter, 2006).

This paper builds upon recent discourse within open innovation to examine the involvement of eleven different parties during the NPD project. The involvement of suppliers, entrepreneurs, customers, universities, consultants, open innovation intermediaries, and even competitors, creates a more 'open' process involving both the inbound acquisition of innovation from external sources and the outbound exploitation of innovations on the external market (Chesbrough, Vanhaverbeke, and West, 2006). Early research suggests that open innovation has a variety of benefits including compressed development time, reduced costs 
and risks, enhanced product attributes, and better overall innovation performance (Faems, Van Looy, and Debackere, 2005; Mishra and Shah, 2009).

The majority of open innovation studies take a firm level unit of analysis, analysing the extent to which a firm's innovation strategy can be considered 'open'. While this unit of analysis is befitting of open innovation's strategic management heritage, studies of industry practice show that innovation takes place within the innovation project itself (Oke and Idiagbon-Oke, 2010; Verma, Mishra, and Sinha, 2011). Therefore, we argue that a more granular unit of analysis is appropriate to the study of open innovation as the number of partners and their level of involvement depends on the goals of the individual new product development project (Du, Leten, and Vanhaverbeke, 2014). Our study therefore adopts the project level unit of analysis and seeks to make three contributions to the operations management literature.

Our first contribution relates to the study of additional external parties within NPD projects. Extant literature has studied the antecedents, moderators and performance outcomes of integrating suppliers into the project (Song and Di Benedetto, 2008; Yan and Dooley, 2013), however, industry now seeks to include a broader range of parties including entrepreneurs, customers, universities, consultants, open innovation intermediaries, and competitors (Laursen and Salter, 2006; Mishra and Shah, 2009). By adopting a project level unit of analysis, our perspective is complementary to the extant operations management literature and uncovers effects that may otherwise remain hidden in the study of any single partner.

Second, we develop and test a new multidimensional measurement scale for the level of openness within NPD projects. While previous studies primarily rely on a count of the external knowledge sources involved in the innovation (Laursen and Salter, 2006; Roper and Arvanitis, 2012), critics have called for the development of further dimensions (Bahemia and 
Squire, 2010). Indeed, studies of supplier involvement in new product development (SINPD) have long since established that outcomes are determined not just by the number of parties involved in the project, but also by the type and extent of involvement (Lawson et al., 2009; Primo and Amundson, 2002). Following prior conceptual development (Bahemia and Squire, 2010), we measure openness as consisting of three dimensions: breadth, the number and activities of different types external partners involved in the project; depth, the pattern of interaction and information sharing between the focal firm and the external partners during the project; and, partner newness, the number of new (as opposed to existing) external partners engaged in the project.

Finally, we propose and empirically test the effect of each dimension on product innovativeness and product competitive advantage. The literature is mixed on the impact of openness with studies finding positive, negative and non-linear effects, as well as different results for radical and incremental innovations (e.g. Faems et al., 2005; Laursen and Salter, 2006; Garriga et al., 2013; Salge et al., 2013). Our study builds on this body of work to provide a more granular analysis of the three dimensions of openness within the specific context of the NPD project.

The rest of the paper is organised as follows. In Section 2, we start with a review of the literature on open innovation, the benefits of openness and appropriability regimes. In Section 3, the theoretical framework and hypotheses for the research are presented. In Section 4, we describe the research method followed by the presentation of results in Section 5. In Section 6, we discuss our findings and contribution to theory. Finally, we conclude with a brief summary on the limitations and opportunities for future research in Section 7.

\section{Open Innovation and NPD}

\subsection{Open innovation}


Innovation was traditionally considered to be a linear process, starting with basic research and ending with the development of new products. This linear model represents the first generation innovation process of the 1950's and has evolved over time through five distinct stages (Rothwell, 1994). The fifth, and most recent, innovation stage is exemplified by a networked approach to innovation where the boundaries of the firm become more porous and there is a strong focus on improving the efficiency and speed of the development process; this is referred to as 'open innovation'. The open innovation model has two dimensions: inbound and outbound (Chesbrough, 2003). Inbound refers to leveraging the research and development of external agents and acquiring external knowledge resources to develop new products. On the other hand, outbound refers to the commercialisation of internal research and the development of outputs for external organisations such as, licensing, joint ventures and spin-offs (West and Bogers, 2013). This paper focuses on the inbound process.

The dimensions and measurement of openness have evolved since its original conception (West, Salter, Vanhaverbeke, and Chesbrough, 2014). The most commonly studied dimension is 'breadth of openness', and refers to the number of different types of external partner, or sources of information, involved in the innovation process (Laursen and Salter, 2006). Although less common, open innovation scholars have also examined the 'depth of openness'. This is defined as the intensity of collaboration between the firm and the external parties during the innovation process (Keupp and Gassmann, 2009) and is similar to the integration construct commonly found in studies of SINPD, albeit with a broader number of different parties. Following Bahemia and Squire (2010), and drawing on March's (1991) theory of exploration and exploitation, our study adds a third dimension to the study of openness. Prior studies have argued that the twin processes of expanding an innovation network to include new partners and reinforcing the network with existing partners are similar to the concepts of exploration and exploitation respectively (Beckman, Haunschild, and 
Phillips, 2004; Lin, Yang, and Demirkan, 2007). Our third dimension, partner newness, therefore examines the number of new parties involved in the new product development project.

\subsection{The benefits of open innovation for innovation performance}

Opening the NPD project to external parties has been found to have a positive effect on a wide range of innovation outcomes. Firstly, scholars have examined the effect of open innovation on product level outcomes. Firms that possess a heterogeneous innovation network of different partners, such as suppliers, customers and universities, have a better turnover realized from both technologically new and improved products (Faems et al., 2005; Zeng et al., 2010). Network heterogeneity provides access to diverse sources of knowledge that can be combined to develop products that are more innovative than those created through single partner collaborations (Nieto and Santamaria, 2007). Secondly, scholars have also examined the effect of open innovation on organizational level outcomes. Within the service sector, Love et al. (2011) find that a high degree of openness to external ideas, combined with internal connectivity and teamworking, significantly improves innovation diversity and business growth. Such improvements to product innovation have also been found to have direct benefits to the percentage share of sales of new products (Inauen and Schenker-Wicki, 2011) and indirect benefits to a company's profit margin (Faems et al., 2010).

On the other hand, studies of openness are not universally positive. There may be limits to the number of partners that are beneficial (Laursen and Salter, 2006: Grimpe and Kaiser, 2010), and poor implementation of open innovation can actually lead to detrimental outcomes (Ciravegna and Maielli, 2011). Such equivocal results have lead scholars to call for more research into contingencies that might enable firms to access external knowledge for innovation and capture its value (Bianchi et al., 2016). A core contingency within open NPD 
projects is the firm's appropriability regime (Laursen and Salter, 2014) and this is explored in the next section.

\subsection{Openness and appropriability}

One of the major risks of 'openness' is the potential loss of intellectual property (Van Dijk, 2000). The appropriability regime is therefore a key ingredient of successful innovation (Laursen and Salter, 2014). Although firms invest resources to achieve value creation during their innovation process, this alone does not provide firms with a sustainable competitive advantage. Firms should not only invest in value creation but also in value appropriation (Arrow, 1962). Ease of duplication by competitors and imitators acts as a disincentive for innovators because it becomes difficult for firms to sustain long-term returns on $R \& D$ because of the appropriation of profits by competitors (Teece, 1986). Therefore, innovators have to erect barriers to prevent competitors and imitators from appropriating rents from their technological innovations by developing a strong appropriability regime (Reed and DeFillippi, 1990; Hurmelinna-Laukkanen et al., 2008).

Within the specific context of open innovation, the strength of the appropriability regime has a concave relationship with openness; gains start to accrue positively but reach an inflection point after which returns become negative (Laursen and Salter, 2014). In other words, a firm's appropriability regime can become overly restrictive to a point whereby it sends a negative signal to potential collaborators. Although we have a better understanding of the relationship between open innovation and the appropriability regime at the firm level, the question of whether a strong regime enables or constrains open innovation has not been addressed by the literature at the level of the project. We seek to address this gap by examining the extent to which the relationship between open NPD projects and innovation outcomes is influenced by the strength of the appropriability regime. 


\section{Theoretical model and hypothesis development}

This study examines the effects of the three dimensions of openness (breadth, partner newness, and depth) on product innovativeness and competitive advantage at the project level. Figure 1 shows our hypothesised model.

\section{Insert Figure 1 about here}

\subsection{Breadth of openness and product innovativeness}

Product innovativeness is defined as a product's newness relative to the firm and the outside world (Song and Parry, 1999). Innovativeness can thus be understood as either macro, industry level technological and market discontinuities, or micro, firm level technical and marketing know-how novelty (Garcia and Calantone, 2002; Calantone et al., 2006). This paper is concerned with macro level innovativeness, products that are new to the industry and the market (Fitjar and Rodriguez-Pose, 2013). Product innovation has the potential to create rents and competitive advantage (McGrath et al., 1996), and therefore firms place a heavy emphasis on knowledge protection in order to secure existing assets as well to as capture gains emerging from the NPD process (Ritala and Hurmelinna-Laukkanen, 2013). The mechanisms used to capture and protect a firm's intellectual assets constitute the appropriability regime (Hurmelinna-Laukkanen et al., 2008). Under a strong regime, organisations have perfect appropriation of their innovations, while under a weak regime, competitors and imitators profit from these innovations, leading to a loss of competitive advantage.

Open innovation projects require permeable organisational boundaries, with an increasing range of external partners, and are therefore exposed to the risk of opportunistic 
behaviour and knowledge misappropriation (Jayaram, 2008). Formal appropriation instruments, such as patents, are important mechanisms to protect firms against the loss of knowledge created during a collaborative innovation process (Levin, Klevorick, Nelson, and Winter, 1987). According to a recent empirical study by Drechsler and Natter (2012), effective formal and strategic IP protection mechanisms are among the major drivers for companies to open up their borders to external partners during the innovation process. Indeed, empirical evidence suggests that open innovation tends to be more prevalent in industries with high appropriability regimes, such as pharmaceuticals, than in industries with low regimes, such as textiles (Laursen and Salter, 2005). Therefore we propose that:

$H_{1}$ : Breadth of openness has a positive relationship with product innovativeness but only in the presence of a strong appropriability regime

\subsection{Partner newness and product innovativeness}

The second dimension of openness, partner newness, represents the proportion of project partners collaborating with the focal firm for the first time. New partners represent structural holes, or the absence of ties, within the network (Ahuja, 2000) and thus reduce a firm's tendency towards homophily, the use of existing similar partners, in the search and development of new ideas (Yan and Dooley, 2013). Specifically, new partners are considered to have positive effects for product innovativenesss because of their impact on the following three areas of the NPD process. Firstly, the level of creativity and innovation performance during NPD projects is enhanced when firms interact with new partners (Baer, 2010). Secondly, new relationships tend to expose projects to new and non-redundant information (Granovetter, 1973), which has been shown to positively influence patenting activity (Hauser, Tappeiner, and Walde, 2007) and innovation outcomes. Thirdly, integrating new external partners into the innovation process can reduce the degree of lock-in and inertia in the mental 
team model, which has the potential to reduce or even stifle the level of project creativity (Bettenhausen and Murnighan, 1991). We therefore hypothesise that:

$\mathrm{H}_{2}$ : There is a positive relationship between partner newness and product innovativeness.

\subsection{Depth of openness and product innovativeness}

Although less common in the literature, depth is considered to be the third dimension of openness (e.g. Laursen and Salter, 2006; Keupp and Gassmann, 2009; Saebi and Foss, 2015). In the supply chain literature, the depth of inter-organisational collaboration tends to be measured by examining the extent of the supplier's involvement in the NPD process (Mishra and Shah, 2009; Swink, 1999). In general terms, scholars argue that an early and high level of integration of suppliers into the NPD process is a critical success factor for the performance of the NPD project (Petersen et al., 2005). Early involvement can have a positive impact on improving the NPD cycle and firm performance leading to a reduction of cost, shorter development cycles and improved process and product design (Bonaccorsi and Lipparini, 1994; Jayaram, 2008; Petersen et al., 2005).

On the other hand, strong ties can have a negative effect on product innovativeness. The strength of tie between two actors or organisations is a function of the time, emotional intensity and reciprocity within the relationship (Granovetter, 1973). Studies of innovation suggest that weak ties are advantageous because they provide access to novel information are are more likely to offer new and foreign ideas (Granovetter, 1973). Subsequent empirical research has found that weak ties improve entrepreneur's innovative action (Ruef, 2002), regional innovation activity (Hauser, 2007), creativity (Baer, 2010) and radical innovation (Ouimet et al., 2004). Organisations might therefore choose to work with those external parties with whom they have arms-length relations to access novel information critical to innovation (Schumpeter, 1934). 
Because we are specifically concerned with product innovativeness, we suggest that depth will have a negative effect. First, embedded or close partners can become overly homogeneous and susceptible to groupthink (Janis, 1989; Selnes and Sallis, 2003). This reduces the possibility that radical outcomes will emerge from the project and therefore favours arms-length arrangements. Second, managers might be concerned with knowledge misappropriation or other similar opportunistic behaviours connected with an open NPD project (Bogers, 2011). This is particularly important for products that are new to the market where preventing knowledge leakage is critical, and therefore might lead firms to be more guarded in their approach to collaboration. Therefore, we hypothesise that:

$H_{3}$ : There is a negative relationship between the depth of openness and product innovativeness.

\subsection{Product innovativeness and product competitive advantage}

Innovation provides firms with a sustained competitive advantage as they can appropriate high rents for a prolonged period (Porter, 1990). According to the resource- based view of the firm, any resource or capability provides firms with a competitive advantage if it is 'valuable, rare, non-imitable and non-substitutable'. Strategies, which emphasise technological and product innovations are more likely to provide firms with a sustained competitive advantage (Utterback and Abernathy, 1975). In the context of new product development projects, product competitive advantage refers to a product's perceived superiority relative to competitive products (Song and Parry, 1999). We suggest that products that are new to an industry or market are more likely to offer unique features and attributes and will be better able to meet customer needs than competitor products. We therefore hypothesise that: 
$H_{4}$ : There is a positive relationship between product innovativeness and product competitive advantage.

\section{Research Methods}

\subsection{Data collection and sample}

The target population for our survey consisted of manufacturing firms in the United Kingdom. Contact details were obtained from the database of The Manufacturer, which is a large commercial database of approximately 140,000 UK manufacturing firms. The survey targeted key informants with selection based on the criteria of the respondent's profile (i.e. engineering and innovation managers), the level of technology (low, medium and high technology), and firm size (minimum of 50 employees). These criteria resulted in a population frame of 1,480 firms.

Respondents were Innovation, R\&D, and Engineering Managers (or equivalent) as preliminary interviews indicated these managers have a high knowledge of the new product development process. As shown in Table 1 our sample has a concentration of firms in the high and high medium technology industries, consistent with the orientation towards high value and knowledge intensive manufacturing in the UK.

\section{Insert Table 1 about here}

In order to improve the response rate, a pre-notification was sent to the respondents explaining the purpose of the research and the expected output. Next, a cover letter was sent to each respondent. The letter included the link to the web-based survey and emphasized that all data would anonymised and kept strictly confidential as preliminary interviews suggested that data regarding new product development projects is particularly sensitive for 
organisations. Several rounds of phone calls considerably increased the response rate. A total of 212 respondents participated in the survey, seven questionnaires were discarded due to incomplete responses which resulted in 205 usable responses. This represents a response rate of $14 \%$ and is deemed to be satisfactory given that it is above the threshold of 12 percent for a population size of 1500 (Bartlett, Kotrlik, and Higgins, 2001).

\subsection{Measures}

The unit of analysis was the NPD project and all questions were formulated to capture open innovation and its outcomes for a specific project. The respondents were asked to choose their last NPD project that involved at least one type of external partner such as suppliers, customers, universities, competitors, commercial laboratories or private and public research institutes. It was also stipulated that the end product had to be launched in the market. All Likert scaled items were measured on a seven-point scale and all measures, except for the breadth of openness, are adapted from existing literature as illustrated in Table 2. Moreover, all multi-item variables used in the regression analysis are created from the mean of the items.

Dependent variables:

Product innovativeness was adapted from the measure of Song and Parry (1999). It represents the novelty of the product to the market and the industry. Product competitive advantage refers to the new product's perceived superiority relative to competitive products. We adopt Song and Parry's (1999) measure that examines the extent to which the product offers unique features, is superior to competing products, enabled the customer to do something new, and is of higher quality than competing products.

Independent variables: 
The breadth of openness is a new scale developed for this research and measures the involvement of eleven different types of external party during a new product development project. The external parties are: suppliers, individual innovators, entrepreneurs, start-up or spin off, customers, crowd sourcing, competitors, consultants, universities or other higher education institutes, government research organisations, commercial laboratories, private research institutes, and open innovation intermediaries. While extant studies typically adopt a nominal scale, we deliberately developed a continuous scale measure to help further understand the multi-dimensional nature of the construct (Nunnally, 1978; Venkatraman and Grant, 1986). Firms engaging in open innovation are changing the manner in which they search for new ideas, processes and technologies for innovation (Laursen and Salter, 2006). However, it is important to recognise that the purpose and process of open innovation varies among projects, firms and industries (Huizingh, 2011). Therefore, in addition to capturing the various partners involved in the project, breadth also needs to identify the various activities through which external parties might be involved in the project.

Following scale development procedures outlined by Hinkin (1995) and De Vellis (2003), the breadth of openness scale was developed based on an in-depth literature review and three rounds of interviews with 16 target respondents to: (1) identify a comprehensive list of different types of external partners involved in open innovation projects; (2) define the theoretical domain of the construct; and (3) pilot test and refine the new measure. In the first stage of the scale development process, we identified a list of different types of external partner likely to be involved during NPD projects. Extant studies capture the breadth of openness by focusing on the degree of openness to traditional sources of knowledge or external partner such as suppliers, customers, consultants, research institutes and universities (Laursen and Salter, 2006; Leiponen and Helfat, 2010; Mol and Birkinshaw, 2009). After conducting the interviews, we also included new types of external partner such as members of 
the crowd, open innovation intermediaries, and individual innovators and entrepreneurs. Next, the items of the measure were generated by means of a deductive approach in order to capture the larger theoretical domain of the construct (Hinkin, 1995; Schwab, 1980). Specifically, we were interested in the activities through which firms collaborate with a mix of different types of external partners to complement internal $\mathrm{R} \& \mathrm{D}$ and to overcome knowledge resource constraints (Castiaux, 2007; Combs and Ketchen Jr, 1999). Finally, the items for the breadth construct, were subjected to further content validity assessment. The feedback from the sixteen interviewees and six academics led to further refinement of the items of the measurement instrument for the breadth construct as presented in Table 2.

Partner newness represents the percentage of new partners involved in the NPD project. Our measure is adapted from Lin et al. (2007) and is calculated as a percentage of the number of new partners involved in the NPD project over the total number of external partners involved in the NPD project. The total number of external partners includes both longstanding ties, i.e. partners from previous projects, and new partners, i.e. first time collaboration for this specific project.

The depth of openness scale captures the level of integration between the firm and the external partners during the NPD projects (García, Sanzo, and Trespalacios, 2008). It represents the way that the firm collaborates with external partners during an NPD project. The scale captures the extent to which the firm and its external partners help one another to accomplish their tasks, try to achieve goals jointly, share ideas, information and resources openly, and take the project's technical and operative decision together (García et al., 2008). We adapt an inter-functional integration measure used in new product development studies to the context of open innovation (Kahn, 1996).

Moderating variable: 
The strength of the appropriability regime scale consisted of two items measuring the effectiveness of a formal appropriation instrument i.e. a patent to prevent duplication and to secure royalties income.

\section{Control variables}

The study controls for four variables that may predict performance; transformational leadership, firm size, project size and industry type. Transformational leadership is a positive force in the context of innovation (Boerner, Eisenbeiss, and Griesser, 2007). We adopted the 7 item Global Transformational Leadership scale developed by Carless et al. (2000). Innovation outcomes have also been shown to be a function of the size of the firm or the project, although the findings regarding the direction and significance of the relationship are mixed (Chandy and Tellis, 1998). Firm size was measured by number of employees, while project size was measured by the total number of individuals involved in the selected NPD project. Finally, prior studies have also suggested that open innovation is sensitive to the type of industry (Chesbrough, 2003). Industry type was based on the OECD (2003) classification of technology level.

\subsection{Convergent and Discriminant Validity}

Confirmatory factor analysis (CFA) was employed (AMOS 20) to assess construct validity and unidimensionality. All indicators were checked for low factor loadings (defined as $<0.40$ ), high residuals (defined as $>2.58$ ) and high modification indices (defined as $>3.84$ ) (Byrne et al., 2001; Hair et al.,2006). As a result, one item (item 2c in Table 2) was removed due to low loadings. All standardised residuals and modification indices were deemed acceptable and therefore no correlated measurement errors were included in the model.

Model fit was tested using four indices: the comparative fit index (CFI); the incremental fit index (IFI); the Tucker-Lewis Index (TLI); and the root mean squared error of approximation index (RMSEA). Values suggest that the fit of the data to the CFA was 
satisfactory: $\mathrm{CFI}=0.962, \mathrm{IFI}=0.962, \mathrm{TLI}=.956$ and $\mathrm{RMSEA}=0.046$. Cronbach's alpha values ranged between 0.78 and 0.96 suggesting satisfactory reliability (Nunnally, 1978). We also examined the convergent validity by calculating the composite reliability developed by Fornell and Larcker (1981), which is considered to be a better choice than Cronbach's alpha (Shook, Ketchen JR, Hult, and Kacmar, 2004). The values of the composite reliability of all constructs are reported in Table 2 and these values are equal to or above the threshold of 0.70 (Nunnally, 1978). In addition, values for the Average Variance Extracted (AVE) were higher than the recommended 0.50 minimum suggesting adequate convergence between each construct and their respective indicators (Byrne, 2001).

We also test the discriminant validity of the constructs: the variance extracted (AVE) estimates are greater than the corresponding inter-constructs square correlation estimates for all constructs, indicating strong discriminant validity. Table 2 reports the item descriptions, loadings, Cronbach's Alpha and the Average Variance Extracted.

\section{Insert Table 2 about here}

\subsection{Common Methods Variance}

Although the interaction effects in our model reduce the threat of common methods variance (Siemsen, Roth, and Oliveira, 2010), we acknowledge that threat to the validity of our results. A Confirmatory Factor Analysis (CFA) was run to detect the presence of common variance method bias. The simple model consisted of one construct loaded on 26 items and the complex model consisted of 26 items loaded on 6 constructs. Model fit substantially improved between the simple $\left(\chi^{2}=1955.4 ; \mathrm{df}=299\right)$ and the complex model $\left(\chi^{2}=407.1 ; \mathrm{df}\right.$ $=284)$. The results suggest that common method variance was not a threat to the validity of the data. 


\section{Results}

Table 3 reports the descriptive statistics and correlations. The Pearson correlation shows that the value for the bivariate correlations is below the threshold value of .80, suggesting that there is no multi-collinearity in the sample data (Tabachnick and Fidell, 2001). We test the hypothesized model with hierarchical multiple regressions. All independent variables were mean centred to reduce possible multi-collinearity in the interaction and quadratic terms (Aiken and West, 1991).

\section{Insert Table 3 about here}

\subsection{Direct and moderating effects}

Figure 1 tests the direct effects of partner newness $\left(\mathrm{H}_{2}\right)$ and depth $\left(\mathrm{H}_{3}\right)$ on product innovativeness, as well as the interaction effect between breadth and the strength of the appropriability regime $\left(\mathrm{H}_{1}\right)$. Of our control variables, only transformational leadership was significant. As expected, transformative leaders can have a positive effect on the level of product innovativeness. In support of $\mathrm{H}_{1}$, Table 4 shows a non-significant direct relationship between breadth and product innovativeness that becomes significantly positive in the presence of a strong appropriability regime $(\beta=0.124 \mathrm{p}<0.05)$. To further analyse the significant interaction effect we plotted the relationships using values of one standard deviation above the mean to represent a strong regime and one standard deviation below the mean to represent a weak regime (Cohen and Cohen, 1983). The figure indicates that under a weak regime, breadth of openness has a negative relationship to product innovativeness but that this turns positive when the regime becomes strong. 


\author{
Insert Figure 2 about here
}

In support of $\mathrm{H}_{2}$, we find a positive direct relationship between the partner newness and product innovativeness $(\beta=0.141, \mathrm{p}<0.05)$ indicating that the integration of new partners into the NPD project has a positive effect on product innovativeness. As predicted $\left(\mathrm{H}_{3}\right)$, we find a significant negative relationship between the depth dimension of openness and product innovativeness $(\beta=-0.126, p<.05)$, suggesting innovations are more likely to emerge from arms-length relations.

Insert Table 4 about here

\title{
5.2 Performance outcomes
}

Results in table 5 provide support to $\mathrm{H}_{4}(\beta=0.438, \mathrm{p}<.001)$. As anticipated, product innovativeness has a significant positive relationship with product competitive advantage. Products that are new to the market or industry are perceived to be superior to their competitor's offerings and are more aligned with the needs of their customers.

\section{Insert Table 5 about here}

\section{Discussion}

\subsection{Theoretical contributions}

While there is extensive discourse on supplier involvement in the operations management literature (Petersen et al., 2005; Najafi Tavani et al., 2013), these studies tend not to focus on the contribution and the dynamics of the involvement of other external parties during the NPD project; it is this knowledge gap that we aimed to address. We have 
investigated the involvement of up to eleven different types of external partner and found that the breadth, depth of openness and partner newness have significant effects for product innovativeness, and indirectly on product competitive advantage.

Our first contribution relates to the study of a broad variety of external parties within the NPD project. Operations management scholars have provided substantial insights into the antecedents, moderators and performance outcomes of integrating suppliers into NPD projects (Primo and Amundson, 2002; Song and Di Benedetto, 2008; Yan and Dooley, 2013). Whilst this research is extremely valuable and offers key insights into our understanding of the NPD process, industry practice has started to shift to the concurrent integration of multiple types of partner within a single NPD project (Mishra and Shah, 2009). By adopting a multi-partner, project level unit of analysis, our perspective is complementary to the extant literature and offers additional insights that would remain hidden within the study of a single type of partner (e.g. supplier). Specifically, our research suggests that positive gains accrue from opening the NPD project to multiple types of partner but only in the presence of a strong appropriability regime. The results indicate that appropriability might be an enabler, or hygiene factor, that gives organisations the confidence to leverage their external environment within their NPD projects (Laursen and Salter, 2014). Figure 2 shows that open NPD projects with weak appropriability regimes will result in less innovative products than closed NPD projects. In other words, firms that fear misappropriation are more likely to rely on their internal R\&D functions for those products that are new to the world or market, or only use open NPD for projects that are less innovative in nature.

Second, we develop the definition of openness (collaboration with different types of external partner) from the extant uni-dimensional perspective (breadth of openness) towards a multi-dimensional conceptualisation, including breadth, depth and the partner newness. Building on prior conceptual development (Bahemia and Squire, 2010), these additional 
dimensions provide a deeper understanding of what influences openness, allowing the firm to consider how to manage its partners and appropriability regime to maximise returns for each NPD project. When firms open up the innovation process to different types of external partner such as suppliers, customers, universities, and consultants, benefits accrue to projects that refresh inter-organisational relationships by working with new partners. Moreover, firms should take a cautious approach when managing collaborations with external partners. Our findings suggest that truly innovative products emerge from arms-length relationships as opposed to collaborative arrangements.

\subsection{Managerial Implications}

Our study suggests that there are gains from open NPD projects but that it is only beneficial to open the innovation process to a broad range of external partners when the appropriability regime is strong. Given the need to create new knowledge in innovation projects, patents provide a good short-term control to opportunistic behaviour, reducing the risks of losing intellectual property and fears of knowledge misappropriation (Levin et al., 1987). Overall our results indicate that a strong appropriability regime is an enabler to the inclusion of different types of partner during innovation projects associated with products that are new to the market or industry.

Interestingly, we find a negative relationship between the depth of openness and product innovativeness. Following recent theorising on the dark side of buyer-supplier relationships (Villena et al., 2011), our results suggest that firms are developing a guarded approach to the management of open NPD projects that are established to deliver products that are new to the market or industry. Shallow relationships enable firms to access new ideas and improve the heterogeneity of those ideas (Janis, 1989; Selnes and Sallis, 2003). Moreover, they reduce the possibility of knowledge misappropriation or leakage. There is therefore a fine balancing act 
for the project manager to balance partner interests with the successful completion of the project.

In addition, we found a significant positive link between partner newness and product innovativeness. The findings suggest that the propensity to generate innovations increases from the process of reconfiguring inter-organisational relationships by collaborating with new external partners during the NPD project. Social capital theory suggests that new knowledge is likely to be found in weak ties (Granovetter, 1973), and is therefore consistent with a strategy of forging relationships with new partners, as opposed to solely relying on existing arrangements, during the innovation process. Similarly, integrating new external partners into a NPD project reduces inertia in the mental team model, which is likely to stifle the level of creativity (Bettenhausen and Murnighan, 1991).

\section{Conclusions, limitations and future research}

Building on the SINPD literature, our research set out to examine the effect of including eleven different types of external parties within a NPD project. We develop and test a novel measurement scale that examines three dimensions of 'openness': breadth, depth and partner newness. We find that each has a different relationship with product innovativeness. Breadth has a positive effect but only in the presence of a strong appropriability regime, depth a direct negative effect, and partner newness has a direct positive effect. We also find that product innovativeness has a direct positive relationship with product competitive advantage.

Any research project has its limitations and ours is no exception. First, we accept that there may be national or cultural bias to our sample. Previous studies indicate contrasting approaches in the organisation of open innovation between UK and Germany due to the existence of different social norms and institutional context between the two nations (Love 
and Roper, 2004). Future research could examine whether the relationships of our model hold in other national contexts.

Second, this study is cross-sectional and results are based on single respondents. While our approach provides strong insights into the direct and contingent effects of an open approach to NPD, future studies may complement and extend our findings through a longitudinal case study methodology. We encourage future studies to search for further contingencies. These might include an assessment of how openness varies across the stages of the NPD process, and/or other types of appropriation mechanism, such as secrecy or first mover advantage. We suggest future research also examines the risks of open innovation in more detail and the extent to which a contingent approach can reduce the possible downsides. 


\section{References}

Ahuja, G., 2000. Collaboration networks, structural holes, and innovation: A longitudinal study. Administrative science quarterly, 45(3), pp.425-455.

Aiken, L. S., and West, S. G. 1991. Multiple regression: testing and interpreting interactions. Newbury Park, CA: Sage Publications Inc.

Arrow, K. 1962. Economic welfare and the allocation of resources for invention, The rate and direction of inventive activity: Economic and social factors: 609-626: Nber.

Baer, M. 2010. The strength-of-weak-ties perspective on creativity: a comprehensive examination and extension. Journal of Applied Psychology, 95(3): 592.

Bahemia, H., and Squire, B. 2010. A contingent perspective of open innovation in new product development projects. International Journal of Innovation Management, 14(04): 603-627.

Bartlett, J. E., Kotrlik, J. W., and Higgins, C. C. 2001. Organizational Research: Determining Appropriate Sample Size in Survey Research. Information Technology, Learning, and Performance Journal, 19(1).

Beckman, C. M., Haunschild, P. R., and Phillips, D. J. 2004. Friends or strangers? Firmspecific uncertainty, market uncertainty, and network partner selection. Organization science, 15(3): 259-275.

Bettenhausen, K. L., and Murnighan, J. K. 1991. The development of an intragroup norm and the effects of interpersonal and structural challenges. Administrative Science Quarterly: 20-35.

Bianchi, M., Croce, A., Dell'Era, C., Di Benedetto, C. A., \& Frattini, F. 2016. Organizing for inbound open innovation: How external consultants and a dedicated R\&D unit influence product innovation performance. Journal of Product Innovation Management: 33(4): 492-510.

Boerner, S., Eisenbeiss, S. A., and Griesser, D. 2007. Follower behavior and organizational performance: The impact of transformational leaders. Journal of Leadership and Organizational Studies, 13(3): 15-26.

Bogers, M. 2011. The open innovation paradox: knowledge sharing and protection in R\&D collaborations. European Journal of Innovation Management, 14(1): 93-117.

Bonaccorsi, A.,and Lipparini, A. 1994. Strategic partnerships in new product development: An Italian case study. The Journal of Product Innovation Management, 11(2): 134.

Byrne, B. M. 2001. Structural equation modeling with AMOS: Basic concepts, applications and programming. Mahwah, New Jersey: Lawrence Erlbaum Associates.

Calantone, R. J., Chan, K., and Cui, A. S. 2006. Decomposing product innovativeness and its effects on new product success. Journal of Product Innovation Management, 23(5): 408-421.

Carless, S. A., Wearing, A. J., \& Mann, L. 2000. A short measure of transformational leadership. Journal of Business and Psychology, 14(3): 389-405.

Castiaux, A. 2007. Radical innovation in established organizations: Being a knowledge predator. Journal of Engineering and Technology Management, 24(1): 36-52.

Chandy, R. K., and Tellis, G. J. 1998. Organizing for radical product innovation: The overlooked role of willingness to cannibalize. Journal of Marketing Research, 35(4): 474-487.

Chesbrough, H., Vanhaverbeke, W., and West, J. 2006. Open innovation: Researching a new paradigm: Oxford university press.

Chesbrough, H. W. 2003. The era of open innovation. MIT Sloan Management Review(Spring): 35-41. 
Ciravegna, L. and Maielli, G. 2011. Outsourcing of new product development and the opening of innovation inmature industries: a longitudinal study of Fiat during crisis and recovery. International Journal of Innovation Management, 15(1): 69-93.

Cohen, J., and Cohen, P. 1983. Applied multiple regression/correlation analyses for the behavioral sciences. Hillsdale, NJ: Lawrence Erlbaum Associates.

Combs, J. G., and Ketchen, D. J. 1999. Explaining interfirm cooperation and performance: toward a reconciliation of predictions from the resource-based view and organizational economics. Strategic Management Journal, 20(9): 867-888.

DeVellis, R. F. 2003. Scale development: theory and applications (2nd ed.). Newbury Park, CA: Sage Publications.

Drechsler W.,and Natter, M. 2012. Understanding a firm's openness decisions in innovation. Journal of Business Research, 65: 438-445

Du, J., Leten, B., and Vanhaverbeke, W. 2014. Managing open innovation projects with science-based and market-based partners. Research Policy, 43(5): 828-840.

Faems, D., Van Looy, B., and Debackere, K. 2005. Interorganisational collaboration and innovation: Toward a portfolio approach. The Journal of Product Innovation Management, 22(3): 238-250.

Faems, D., de Visser, M., Andries, P. and van Looy, B. 2010. Technology Alliance Portfolios and Financial Performance: Value-Enhancing and Cost-Increasing Effects of Open Innovation. Journal of Product Innovation Management, 27(6): 785-796.

Fitjar, R. D., and Rodríguez-Pose, A. 2013. Firm collaboration and modes of innovation in Norway. Research Policy, 42(1): 128-138.

Fornell, C., and Larcker, D. F. 1981. Evaluating structural equation models with unobservable variables and measurement error. Journal of Marketing Research, 18(1): 39-50.

Frohlich, M. T., and Westbrook, R. 2001. Arcs of integration: an international study of supply chain strategies. Journal of Operations Management, 19(2): 185-200.

Garcia, R., and Calantone, R. 2002. A critical look at technological innovation typology and innovativeness terminology: a literature review. Journal of Product Innovation Management, 19(2): 110-132.

García, N., Sanzo, M. J., and Trespalacios, J. A. 2008. New product internal performance and market performance: Evidence from Spanish firms regarding the role of trust, interfunctional integration, and innovation type. Technovation, 28(11): 713-725.

Garriga, H., von Krogh, G., and Spaeth, S. 2013. How constraints and knowledge impact open innovation. Strategic Management Journal, 34(9): 1134-1144.

Ginsberg, A., and Venkatraman, N. 1985. Contingency perspectives of organizational strategy: a critical review of the empirical research. Academy of Management Review, 10(3): 421-434.

Granovetter, M. 1973. The strength of weak ties. American Journal of Sociology, 78(6): 1360-1380.

Grimpe, C. and Kaiser, U. 2010. Balancing Internal and External Knowledge Acquisition: The Gains and Pains from R\&D Outsourcing C. Grimpe and U. Kaiser R\&D Outsourcing. Journal of Management Studies, 47(8): 1483-1509.

Hair, J. F., Anderson, R. E., and Tatham, R. L. 2006. Multivariate data analysis: Published Upper Saddle River, N.J. ; London : Prentice Hall PTR 2006

Hauser, C., Tappeiner, G., and Walde, J. 2007. The learning region: the impact of social capital and weak ties on innovation. Regional Studies, 41(1): 75-88.

Hinkin, T. R. 1995. A review of scale development practices in the study of organisations. Journal of Management, 21(5): 967-988.

Huizingh, E. K. 2011. Open innovation: State of the art and future perspectives. Technovation, 31(1): 2-9. 
Hurmelinna-Laukkanen, P., Sainio, L. M., and Jauhiainen, T. 2008. Appropriability regime for radical and incremental innovations. R\&D Management, 38(3): 278-289.

Inauen, M., and Schenker-Wicki, A. 2011. The impact of outside-in open innovation on innovation performance. European Journal of Innovation Management, 14(4), 496520.

Janis, I.L., 1989. Crucial decisions: Leadership in policymaking and crisis management. Simon and Schuster

Jayaram, J. 2008. Supplier involvement in new product development projects: dimensionality and contingency effects. International Journal of Production Research, 46(13): 3717 .

Kahn, K. B. 1996. Interdepartmental integration: a definition with implications for product development performance. Journal of product innovation management, 13(2): 137151.

Keupp, M. M., and Gassmann, O. 2009. Determinants and archetype users of open innovation. R\&D Management, 39(4): 331-341.

Laursen, K., and Salter, A. 2005. The paradox of openness: appropriability and the use of external sources of knowledge for innovation. Paper presented at the Academy of Management Conference, Hawaii.

Laursen, K., and Salter, A. 2006. Open for innovation: the role of openness in explaining innovation performance among UK manufacturing firms. Strategic management journal, 27(2): 131-150.

Laursen, K., and Salter, A. J. 2014. The paradox of openness: Appropriability, external search and collaboration. Research Policy, 43(5): 867-878.

Lawson, B., Petersen, K. J., Cousins, P. D., and Handfield, R. B. 2009. Knowledge sharing in interorganizational product development teams: the effect of formal and informal socialization mechanisms. Journal of Product Innovation Management, 26(2): 156172.

Leiponen, A., and Helfat, C. E. 2010. Innovation objectives, knowledge sources, and the benefits of breadth. Strategic Management Journal, 31(2): 224-236.

Levin, R. C., Klevorick, A. K., Nelson, R. R., and Winter, S. G. 1987. Appropriating the returns from industrial research and development. Brookings Papers on Economic Activity, 3: 783-820.

Lin, Z., Yang, H., and Demirkan, I. 2007. The performance consequences of ambidexterity in strategic alliance formations: Empirical investigation and computational theorizing. Management Science, 53(10): 1645-1658.

Love, J. H., and Roper, S. 2004. The organisation of innovation: collaboration, cooperation and multifunctional groups in UK and German manufacturing. Cambridge Journal of Economics, 28(3): 379-395.

Love, J. H., Roper, S., and Bryson, J. R. (2011). Openness, knowledge, innovation and growth in UK business services. Research Policy, 40(10), 1438-1452.

McGrath, R.G., Tsai, M.H., Venkataraman, S. and MacMillan, I.C., 1996. Innovation, competitive advantage and rent: A model and test. Management Science, 42(3), pp.389-403.

Mol, M.J. and Birkinshaw, J., 2009. The sources of management innovation: When firms introduce new management practices. Journal of business research, 62(12), pp.12691280 .

March, J. G. 1991. Exploration and exploitation in organizational learning. Organization Science, 2(1): 71-87. 
Mishra, A. A., and Shah, R. 2009. In union lies strength: Collaborative competence in new product development and its performance effects. Journal of Operations Management, 27(4): 324-338.

Najafi Tavani, S., Sharifi, H., and S. Ismail, H. 2013. A study of contingency relationships between supplier involvement, absorptive capacity and agile product innovation. International Journal of Operations and Production Management, 34(1): 65-92

Nieto, M. J., and Santamaría, L. (2007). The importance of diverse collaborative networks for the novelty of product innovation. Technovation, 27(6): 367-377.

Nunnally, J. C. 1978. Psychometric theory (2nd ed.). New Delhi: Tata McGraw-Hill.

Oke, A., and Idiagbon-Oke, M. 2010. Communication channels, innovation tasks and NPD project outcomes in innovation-driven horizontal networks. Journal of Operations Management, 28(5): 442-453.

Ouimet, M., Landry, R., and Amara, N. 2004. Network Positions and Radical Innovation: a social network analysis of the Quebec optics and photonics cluster. In DRUID Summer conference.

Porter. 1990. The Competitive Advantage of Nations: New York: Free Press, 1990

Petersen, K. J., Handfield, R. B., and Ragatz, G. L. 2005. Supplier integration into new product development: Coordinating product, process and supply chain design. Journal of Operations Management, 23(4): 371-388.

Primo, M. A. M., and Amundson, S. D. 2002. An exploratory study of the effects of supplier relationships on new product development outcomes. Journal of Operations Management, 20(1): 33-52.

Reed, R., and DeFillippi, R. J. 1990. Causal ambiguity, barriers to Imitation, and sustainable competitive advantage. Academy of Management Review, 15(1): 88-102.

Ritala, P. and P. Hurmelinna-Laukkanen 2013. Incremental and Radical Innovation in Coopetition-The Role of Absorptive Capacity and Appropriability. Journal of Product Innovation Management 30(1): 154-169.

Roper, S., and Arvanitis, S. 2012. From knowledge to added value: A comparative, panel-data analysis of the innovation value chain in Irish and Swiss manufacturing firms. Research Policy, 41(6): 1093-1106.

Rothwell, R. 1994. Towards the fifth-generation innovation process. International Marketing Review, 11(1): 7-31.

Ruef, M., 2002. Strong ties, weak ties and islands: structural and cultural predictors of organizational innovation. Industrial and Corporate Change, 11(3), pp.427-449.

Saebi, T., and Foss, N. J. 2015. Business models for open innovation: Matching heterogeneous open innovation strategies with business model dimensions. European Management Journal, 33(3): 201-213.

Salge, T. O., Farchi, T., Barrett, M. I., and Dopson, S. 2013. When Does Search Openness Really Matter? A Contingency Study of Health-Care Innovation Projects. Journal of Product Innovation Management, 30(4): 659-676.

Schwab, D. P. 1980. Consruct validity in organizational behavior. Research in Organizational Behavior, 2: 3.

Schumpeter, J. A. 1934. The theory of economic development: Cambridge, Mass.: Harvard University Press, 1934.

Selnes, F., Sallis, J., 2003. Promoting relationship learning. Journal of Marketing 67(3), 8095

Shook, C. L., Ketchen JR, D. J., Hult, G. T. M., and Kacmar, M. 2004. An assessment of the use of structural equation modeling in strategic management research. Strategic Management Journal, 25: 397-404. 
Siemsen, E., Roth, A., and Oliveira, P. 2010. Common method bias in regression models with linear, quadratic, and interaction effects. Organizational research methods, 13(3): 456-476.

Song, M., and Di Benedetto, C. A. 2008. Supplier's involvement and success of radical new product development in new ventures. Journal of Operations Management, 26(1): 122.

Song, X. M., and Parry, M. E. 1999. Challenges of managing the development of breakthrough products in Japan. Journal of Operations Management, 17(6): 665-688.

Swink, M. 1999. Threats to new product manufacturability and the effects of development team integration processes. Journal of Operations Management, 17(6): 691-709.

Tabachnick, B. G., and Fidell, L. S. 2001. Using multivariate statistics (4th ed.). Boston, MA: Allyn and Bacon.

Teece, D. J. 1986. Profiting from technological innovation: implications for integration, collaboration, licensing and public policy. Research Policy, 15: 285-306.

Utterback and Abernathy. 1975. A dynamic model of process and product innovation. Omega, 33(6): 639-656.

Van Dijk, M. 2000. Technological regimes and industrial dynamics: the evidence from Dutch manufacturing. Industrial and Corporate Change, 9(2): 173-194.

Venkatraman, N., and Grant, J. H. 1986. Construct Measurement in Organizational Strategy Research: A Critique and Proposal. Academy of Management Review, 11(1): 71-87.

Verma, D., Mishra, A., and Sinha, K. K. 2011. The development and application of a process model for R\&D project management in a high tech firm: A field study. Journal of Operations Management, 29(5): 462-476.

Villena, V. H., Revilla, E., \& Choi, T. Y. 2011. The dark side of buyer-supplier relationships: A social capital perspective. Journal of Operations Management, 29(6): 561-576.

West, J., and Bogers, M. 2013. Leveraging external sources of innovation: a review of research on open innovation. Journal of Product Innovation Management.

West, J., Salter, A., Vanhaverbeke, W., and Chesbrough, H. 2014. Open innovation: The next decade. Research Policy, 43(5): 805-811.

Yan, T., and Dooley, K. J. 2013. Communication intensity, goal congruence, and uncertainty in buyer-supplier new product development. Journal of Operations Management, 31(7-8): 523-542.

Zeng, S. Xie, X. M. Xie, and Chi Ming Tam. 2010.Relationship between cooperation networks and innovation performance of SMEs. Technovation 30.3: 181-194. 
FIGURE 1: HYPOTHESISED MODEL

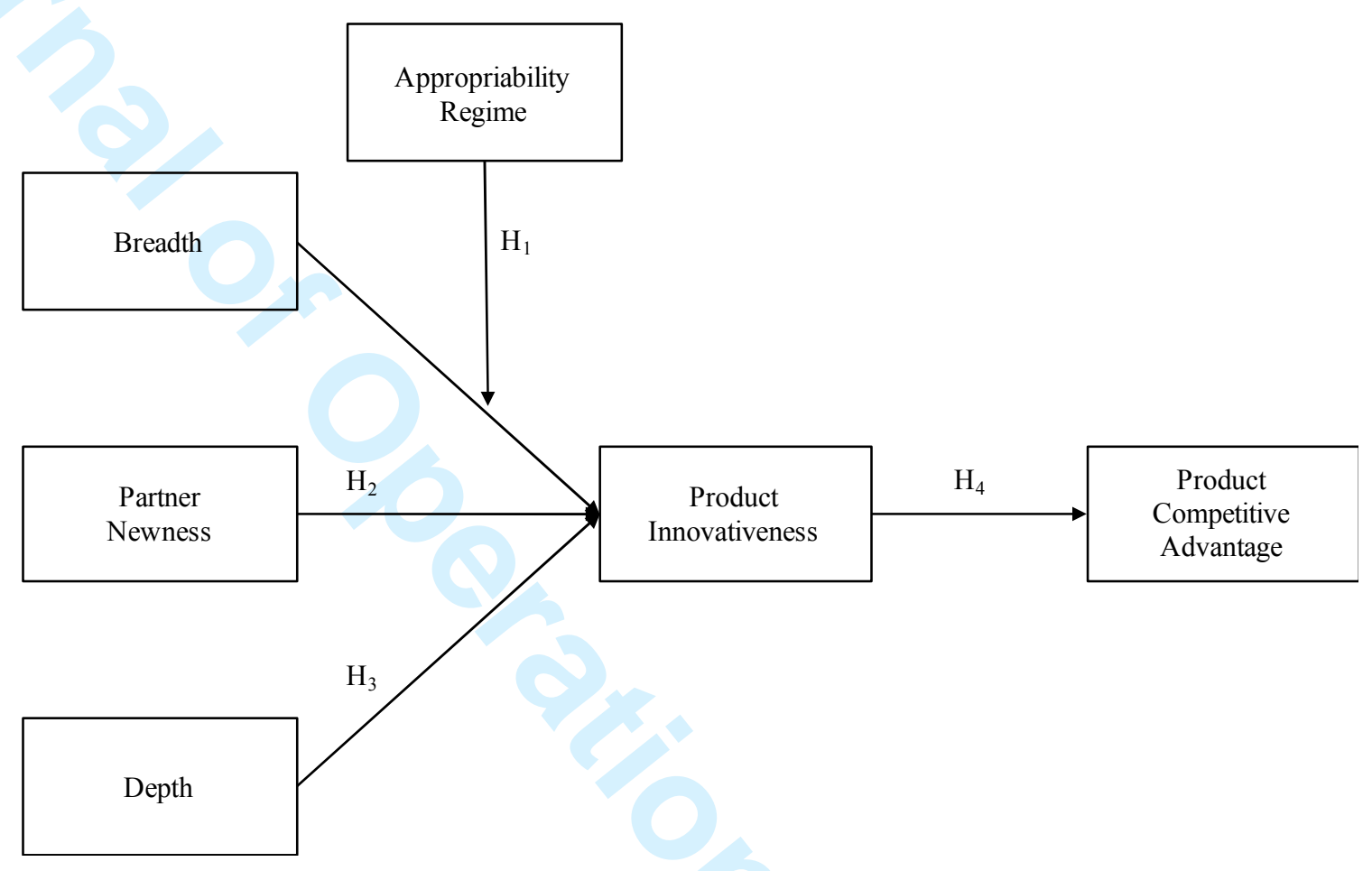


1

2

3

4

5

6

7

8

9

10

11

12

13

14

15

16

17

18

19

20

21

22

23

24

25

26

27

28

29

30

31

32

33

34

35

36

37

38

39

40

41

42

43

44

45

46

47

48

49

50

51

52

53

54

55

56

57

58

59

60

\section{FIGURE 2: INTERACTION MODEL}

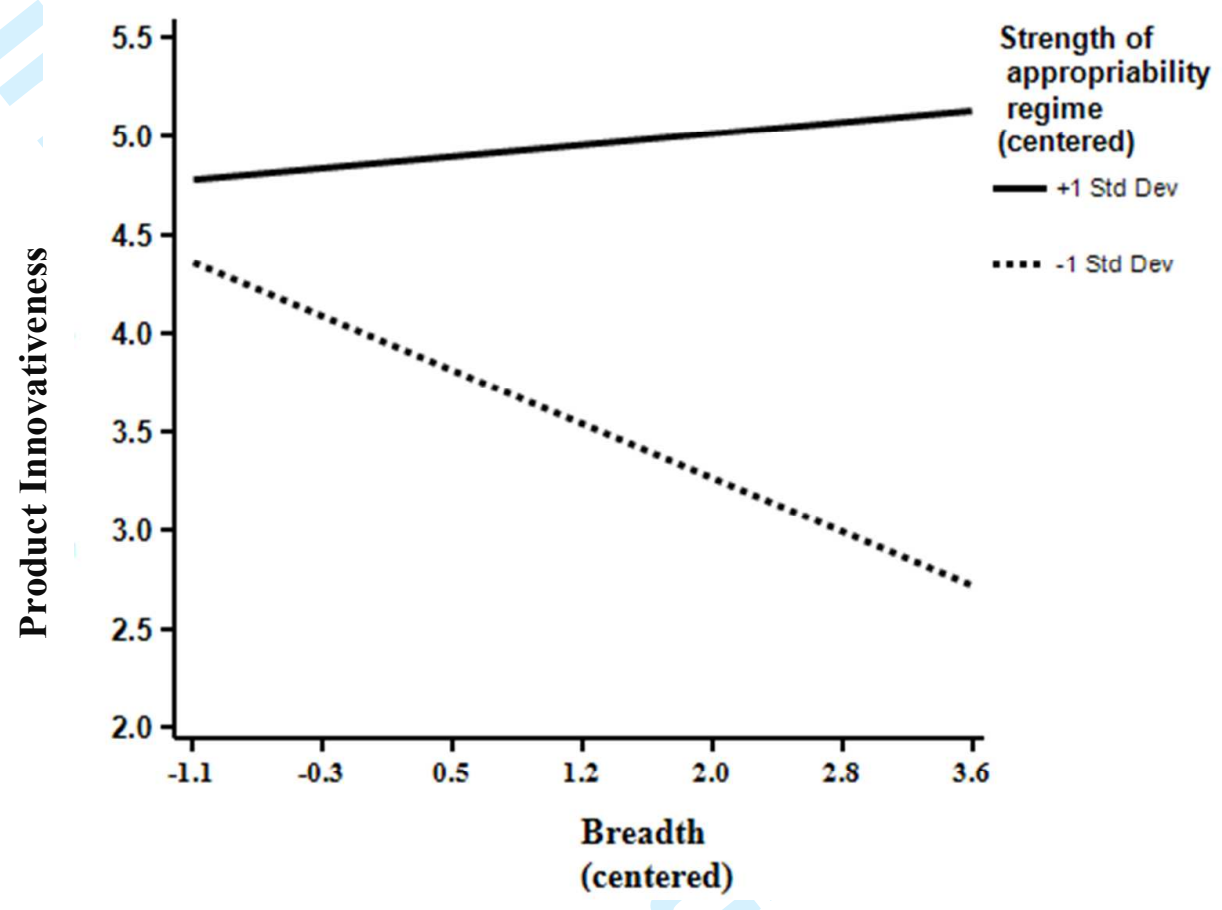


TABLE 1: DESCRIPTIVE STATISTICS OF SAMPLE FRAME

\begin{tabular}{lrr}
\hline Title & Number & Percentage \\
\hline Level of Industry Technology & & \\
\hline High & 63 & 30.7 \\
High-Medium & 91 & 44.4 \\
Medium-Low & 13 & 6.3 \\
Low & 38 & 18.6 \\
TOTAL & 205 & 100 \\
\hline & & \\
Number of employees & & 60.0 \\
\hline $0-200$ & 123 & 21.0 \\
201-500 & 43 & 7.8 \\
501-1000 & 16 & 11.2 \\
1001+ & 23 & 100 \\
TOTAL & 205 & \\
\hline
\end{tabular}


TABLE 2: MEASUREMENTS OF CONSTRUCTS

\section{Constructs and corresponding indicators}

Factor

loading

1. Product Innovativeness $(\alpha=.787 ; \mathrm{CR}=.68 ; \mathrm{AVE}=.50)$

a. This product relied on technology that had never been used in the industry 0.528

b. This product caused significant changes in the whole industry $\quad 0.525$

c. This product was one of the first of its kind introduced into the market 0.616

d. This product was highly innovative- totally new to the market 0.782

2. Product Competitive Advantage $(\alpha=.76 ; \mathrm{CR}=.78 ; \mathrm{AVE}=.55)$

a. Compared to competitive products, this product offered some unique features or

0.835 attributes to the customer.

b. This product was clearly superior to competing products in terms of meeting customers' needs.

c. This product permitted the customer to do a job or do something he could not presently

0.487 do with what was available*.

d. This product was higher quality than competing products-tighter specifications, stronger, lasted longer, or more reliable.

3. Appropriability Regime $(\alpha=.829 ; \mathrm{CR}=.91 ; \mathrm{AVE}=.73)$

a. Patents to prevent duplication

0.958

b. Patents to secure royalties income

0.746

4. Breadth $(\alpha=.872 ; \mathrm{CR}=.88 ; \mathrm{AVE}=.57)$

a. To gain access to new technologies, expertise and know how

0.773

b. To complement our in house research and development capability

0.791

c. To develop the concept of the new product and/or any related process

0.792

d. To design and engineer the new product and/or any related process

0.796

e. To develop and test the prototypes of the new product and/or any related process

0.697

5. Depth $(\alpha=.835 ; \mathrm{CR}=.85 ; \mathrm{AVE}=.53)$

a. Our firm and the external parties helped each other to accomplish their tasks in the most

0.737 effective way.

b. Our firm and the external parties tried to achieve goals jointly.

0.851

c. Our firm and the external parties shared ideas, information and/or resources.

0.767

d. Our firm and the external parties took the project's technical and operative decisions

0.558 together.

e. There was open communication between our firm and the external parties

0.688

\section{Partner Newness}

Percentage of new partners (new partners/total partners in a project)

7. Transformational Leadership $(\alpha=.96 ; \mathrm{CR}=.96 ; \mathrm{AVE}=.78)$

a. My supervisor communicates a clear and positive vision of the future.

0.794

b. My supervisor treats staff as individuals, supports and encourages their development.

0.919

c. My supervisor gives encouragement and recognition to staff.

0.876

d. My supervisor fosters trust, involvement and cooperation among team members.

0.935

e. My supervisor encourages thinking about problems in new ways and questions, assumptions.

0.845

f. My supervisor is clear about his/her value and practices what he/she preaches.

0.885

g. My supervisor instills pride and respect in others and inspires me by being highly

0.902 competent.

\section{Firm Size}

Number of employees in the respondent company 


\section{Project Size}

Total number of individuals involved in the NPD project

10. Industry Type

Dummy variable based on OECD classification (1 if High Tech, Otherwise 0)

All items marked with an * were deleted 
TABLE 3: DESCRIPTIVE STATISTICS AND INTERCORRELATION OF CONSTRUCTS

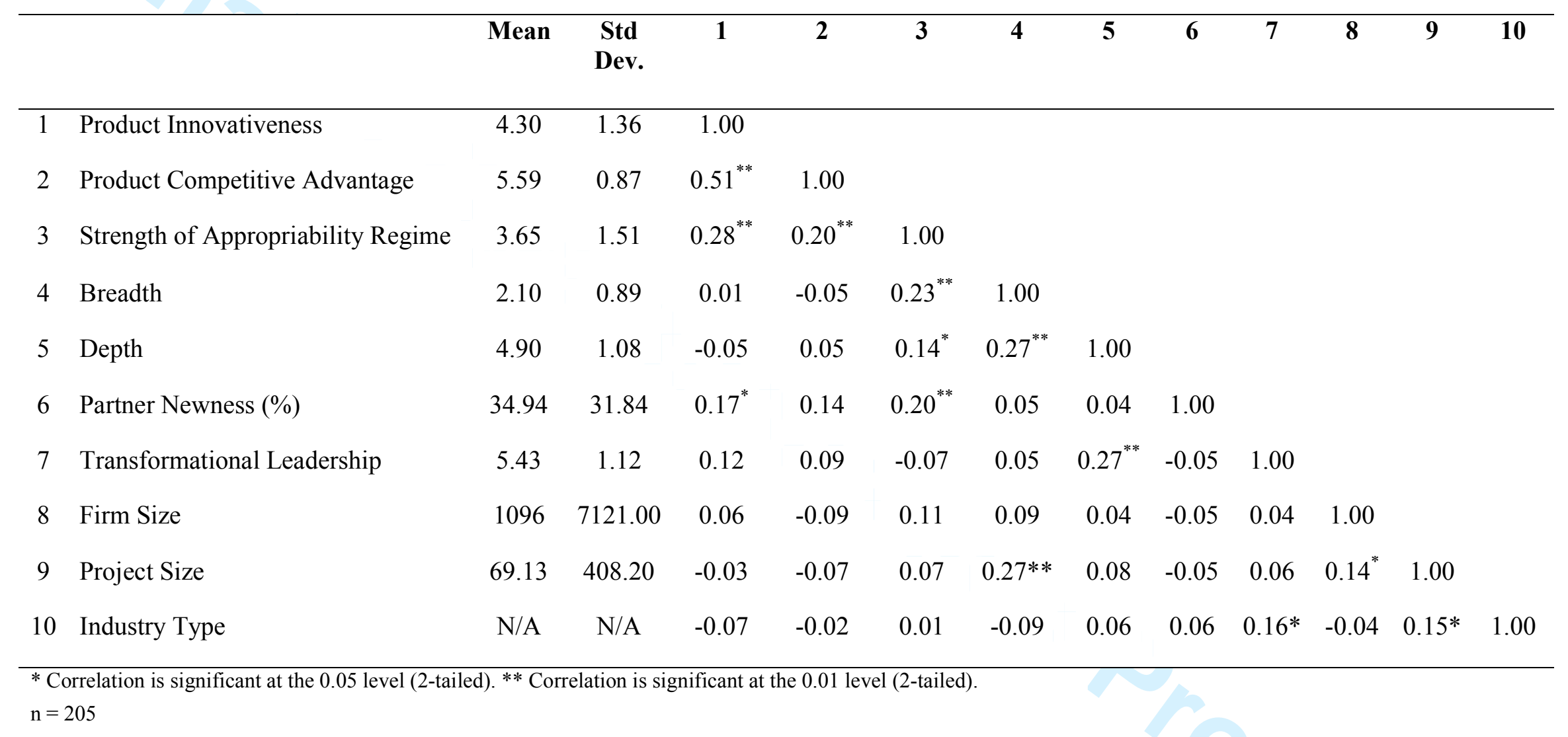


TABLE 4: REGRESSION RESULTS FOR PRODUCT INOVATIVENESS

\begin{tabular}{lccc}
\hline & Step 1 & Step 2 & Step 3 \\
\hline Control Variables & & & \\
Transformational Leadership & $0.1353^{*}$ & $0.203^{* *}$ & $0.208^{* *}$ \\
High Technology Industry & -0.080 & -0.093 & -0.098 \\
Project Size & -0.030 & -0.020 & -0.030 \\
Firm Size & 0.057 & 0.036 & 0.029 \\
& & & \\
Independent Variables & & & \\
Breadth & & -0.052 & -0.084 \\
Partner Newness & & $0.131^{*}$ & $0.142^{*}$ \\
Depth & $-0.130^{*}$ & $-0.126^{*}$ \\
Appropriability Regime & $0.293^{* * *}$ & $0.305^{* * *}$ \\
& & & \\
Interaction Effect & & & $0.122^{*}$ \\
Breadth $\mathrm{x}$ Appropriability Regime & & & \\
$\mathrm{R}^{2}$ & & & 0.156 \\
Adj $\mathrm{R}^{2}$ & 0.025 & 0.142 & 0.116 \\
$\mathrm{R}^{2}$ Change & 0.005 & 0.106 & $0.013^{*}$ \\
\hline${ }^{*}<.05, * * \mathrm{p}<.01,{ }^{* * *} \mathrm{p}<.001, \mathrm{n}=205$ & & $0.117^{* * *}$ &
\end{tabular}

TABLE 5: REGRESSION RESULTS FOR PRODUCT COMPETITIVE ADVANTAGE

\begin{tabular}{lcc}
\hline & Step 1 & Step 2 \\
\hline Control Variables & & \\
Transformational Leadership & 0.097 & 0.029 \\
High Technology Industry & -0.031 & 0.012 \\
Project Size & -0.066 & -0.051 \\
Firm Size & -0.082 & $-0.110^{*}$ \\
& & \\
Independent Variable & & \\
Product Innovativeness & & $0.509 * * *$ \\
& & \\
$\mathrm{R}^{2}$ & 0.021 & 0.275 \\
Adj $\mathrm{R}^{2}$ & 0.002 & 0.255 \\
$\mathrm{R}^{2}$ Change & & $0.253^{* * *}$ \\
\hline${ }^{*}<.05, * * * \mathrm{p}<.001, \mathrm{n}=205$ & &
\end{tabular}

